\title{
СПОСОБ ОПРЕДЕЛЕНИЯ ЧУВСТВИТЕЛЬНОСТИ ХИМИОПРЕПАРАТА К РАКУ МОЛОЧНОЙ ЖЕЛЕЗЫ
}

\section{METHOD FOR DETERMINING \\ THE SENSITIVITY OF A CHEMOTHERAPY DRUG TO BREAST CANCER}

\section{Ramazanov \\ Z. Abdurakhmanova}

Summary. Aim. Development of a new method for determining the sensitivity of a chemotherapy drug to breast cancer, which is available for republican oncological medical institutions. Materials and methods of research. The study included 175 patients with breast cancer (T2$3 \mathrm{~N} 1-2 \mathrm{M0}$ ). The main group included 86 patients, and the comparison group - 89. The developed method for determining the sensitivity of a chemotherapy drug to breast cancer consists in the fact that the material taken from the tumor is treated with a chemotherapy drug for 2 hours, stained with trepan blue and the presence or absence of malignant cells on a slide determines the sensitivity of the chemotherapy drug to breast cancer. Results. After the use of the developed method in the clinic, 86 patients of the main group with breast cancer did not have relapses and metastases. In the comparison group, in 89 patients who did not use the new method for determining the sensitivity of a chemotherapy drug to breast cancer, breast cancer recurrences were found in 9 patients and metastases in 4.

\section{Conclusions}

1. A method for determining the sensitivity of a chemotherapy drug to breast cancer was developed and used in the clinic in 86 patients.

2. Clinical trials have shown that a new method for determining the sensitivity of a chemotherapy drug to breast cancer improves the results of breast cancer chemotherapy.

Keywords: breast cancer, sensitivity of a chemotherapy drug to breast cancer.

\author{
Рамазанов Муталим Рамазанович \\ Д.м.н., доцент, Дагестанский государственный \\ медицинский университет \\ rm.06-50@yandex.ru \\ Абдурахманова Загидат Мутаэлумовна \\ Аспирант, Дагестанский государственный \\ медицинский университет \\ Abdurakhmava@gmail.com
}

Аннотация. Цель. Разработка нового доступного для республиканских онкологических лечебных учреждений способа определения чувствительности химиопрепарата к раку молочной железы. Материалы и методы исследования. В исследование были включены 175 пациенток с раком молочной железы (T2-3N1-2 М0). В основную группу вошли 86 пациенток, а в группу сравнения - 89. Разработанный способ определения чувствительности химиопрепарата к раку молочной железы заключается в том, что материал, взятый из опухоли, обрабатывают химиопрепаратом в течение 2 часов, окрашивают трепановым синим и по наличию или отсутствию злокачественных клеток на предметном стекле определяют чувствительность химиопрепарата к раку молочной железы. Результаты. После применения В клинике разработанного способа у 86 пациенток основной группы с раком молочной железы не установлено рецидивов и метастазов. В группе сравнения у 89 пациенток, у которых не применяли новый способ определения чувствительности химиопрепарата к раку молочной железы, обнаружены рецидивы рака молочной железы у 9 пациенток и метастазы у 4.

Выводы:

1. Разработан способ определения чувствительности химиопрепарата к раку молочной железы и применён в клинике у 86 пациенток.

2. Клинические испытания показали, что новый способ определения чувствительности химиопрепарата к раку молочной железы способствует улучшению результатов химиотерапии рака молочной железы.

Ключевые слова: рак молочной железы, чувствительность химиопрепарата к раку молочной железы.

мость определения индивидуальной чувствительности к раку молочной железы у пациенток к химиопрепарату для того, чтобы улучшить результаты химиотерапии.

Предложенные до настоящего времени способы определения чувствительности химиопрепарата к злокачественной опухоли сложны и в республиканских онкологических лечебных учреждениях их невозможно применять $[4,5,6,7,8,9]$. 


\section{Цель исслеАования}

Разработка нового доступного для республиканских онкологических лечебных учреждений способа определения чувствительности химиопрепарата к раку молочной железы.

\section{Материа^ и методы исследования}

Способ применён у 86 пациенток основной группы с раком молочной железы (T2-3N1-2 M0), а у 89 пациенток группы сравнения с раком молочной железы тех же стадий не применяли.

Предлагаемый способ определения чувствительности химиопрепарата к злокачественной опухоли заключается в следующем (получен патент RU2534410 C2) [10].

У больной берут биопсийный материал троакаром из опухоли молочной железы. С помощью соскоба берут материал с поверхности биопсийного кусочка раковой опухоли и наносят взятый материал на предметное стекло.

Еще одно предметное стекло прилагают к предметному стеклу с раковыми клетками для того, чтобы на обоих предметных стёклах был одинаковый материал.

На предметных стеклах делают метки: контрольный материал и основной материал. Контрольный материал окрашивают по Романовскому - Гимзе на предмет наличия раковых клеток. При наличии раковых клеток, которое подтверждено под микроскопом на контрольном предметном стекле, на основной материал капают 10-15 капель раствора химиопрепарата в соотношении: 4500 мл физиологического раствора и 750 мг фторурацила. Раствор готовят исходя из того, что в организме человека циркулирует в среднем 4500 мл крови, а разовая доза фторурацила составляет 750 мг.

Следовательно, до раковой опухоли пациентки доходит 750 мг фторурацила, растворенного в 4500 мл крови, то есть в соотношении 4500 мл:750 мг. Если сократить соотношение поровну, то получится соответственно:

$$
\frac{4500 \text { мл. }}{10}: \frac{750 \text { мл }}{10}=\frac{450}{15}: \frac{75}{15}=30 \text { мл: 5мг фторурацила. }
$$

Таким образом, в 30 мл физиологического раствора растворяют 5 мг фторурацила и получают в такой концентрации фторурацил, который приблизительно поступает в составе крови к раковой опухоли. Приготовленный раствор фторурацила в соотношении: в 30 мл физиологического раствора растворенный 5 мг фторурацила капают на основной материал раковых клеток на предметное стекло в количестве 10-15 капель на 2 часа. По истечении 2 часов основной материал окрашивают трепановым синим и смотрят под микроскопом. Если на предметном стекле нет раковых клеток или имеются обломки раковых клеток, значит к раку молочной железы пациентки фторурацил чувствителен. В случае обнаружения раковых клеток на предметном стекле (основной материал) то считается, что фторурацил не чувствителен к раку молочной железы данной больной. Вместо фторурацила можно использовать любой другой препарат с помощью аналогичных вычислений по приведённой выше схеме.

Критериями включения пациентов в исследование были: наличие рака молочной железы, информированное письменное согласие пациента на участие в исследовании.

Критерии исключения больных из исследования составили: тяжелая почечная или печёночная недостаточность, хроническая сердечная недостаточность, отказ пациента от участия в данном исследовании.

Критериями выхода больных из исследования были: появление побочных действий лекарственных препаратов; отказ пациента от продолжения исследования и лечения.

Статистическая обработка результатов исследования проводилась с помощью пакета прикладных программ Statistika 10 for Windows. Вычислена средняя арифметическая величина показателей, стандартная ошибка среднего, среднее квадратичное отклонение. Для выяснения значения различия параметров внутри одной группы использовался разностный критерий Стьюдента. Сравнение средних величин разных групп проводилось по двум критериям Стьюдента. Гипотеза нулевого эффекта отвергалась (критический уровень значимости - $\mathrm{P}<$ $0,05)$.

Настоящее исследование одобрено этическим комитетом ФГБОУ ВО «Дагестанский государственный медицинский университет» МЗ РФ от 14 мая 2019 года.

\section{Результаты}

Предоперационная химиотерапия проведена в количестве 4 курсов с определением чувствительности химиопрепарата к раку молочной железы у каждой пациентки (табл. 1).

Режимы химиопрепаратов и их сочетания, применённые нами, приведены в таблице 2 .

В третьей подгруппе основной группы (25) пациенток в стадии T3N2M0 были случаи, когда химиотерапию про- 
Таблица 1. Нозологические формы пациенток, у которых выполнена предоперационная химиотерапия по поводу рака молочной железы

\begin{tabular}{|c|c|c|c|c|c|c|}
\hline \multirow{3}{*}{$\begin{array}{l}\text { Нозологическая форма, } \\
\text { стадия РМЖ }\end{array}$} & \multicolumn{2}{|c|}{$\begin{array}{l}\text { Количество } \\
\text { больных }\end{array}$} & \multicolumn{4}{|c|}{ Рецидивы и метастазы } \\
\hline & \multirow{2}{*}{ ОГ } & \multirow{2}{*}{ ГC } & \multicolumn{2}{|l|}{ ОГ } & \multicolumn{2}{|l|}{ ГC } \\
\hline & & & Рец. & Мет. & Рец. & Мет. \\
\hline $\begin{array}{l}\text { T2N1M0 } \\
\text { /метастаз в подключичный } \\
\text { л/узел }\end{array}$ & 30 & 30 & 0 & 0 & 3 & 1 \\
\hline $\begin{array}{l}\text { T2N1M0 } \\
\text { /метастаз в подмышечный л/ } \\
\text { узел }\end{array}$ & 31 & 32 & 0 & 0 & 2 & 1 \\
\hline $\begin{array}{l}\text { T3N2M0 } \\
\text { /метастазы в подключичный, } \\
\text { подмышечный } \\
\text { и подлопаточный лимфоузлы }\end{array}$ & 25 & 27 & 0 & 0 & 4 & 2 \\
\hline Всего & 86 & 89 & 0 & 0 & 9 & 4 \\
\hline \multirow[t]{2}{*}{ Итого } & \multicolumn{2}{|l|}{175} & \multicolumn{2}{|l|}{0} & 9 & 4 \\
\hline & & & & & \multicolumn{2}{|c|}{$P<0,005$} \\
\hline
\end{tabular}

ОГ-основная группа; ГС-группа сравнения; РМЖ-рак молочной железы; РЕЦрецидив; $\mathrm{MET}$ - метастаз.

Таблица 2. Режимы химиопрепаратов, применённые у 86 пациенток для химиотерапии по поводу рака молочной железы

\begin{tabular}{|c|c|c|c|}
\hline $\begin{array}{l}\text { № } \\
\text { п/п }\end{array}$ & Схема & Название химиопрепарата & Доза химиопрепарата и режимы \\
\hline 1 & CMF & $\begin{array}{l}\text { Циклофосфамид } \\
\text { Метотрексат } \\
\text { Фторурацил }\end{array}$ & $\begin{array}{l}\text { 100мг/м2 внутрь ежедневно с } 1 \text { по 14-й день, } \\
40 \text { мг/м2 в/в в 1-й и 8-й день, } \\
\text { 500мг/м2 в/в в 1-й и 8-й день. } \\
\text { Повторить через } 4 \text { недели (интервал 2. недели). }\end{array}$ \\
\hline 2 & VC & $\begin{array}{l}\text { Винорельбин } \\
\text { Капецитабин }\end{array}$ & $\begin{array}{l}25 \text { мг/м2 в 1, 8, 1 5, } 22 \text { дни, } \\
\text { 1000мг/м2 } 2 \text { р/день (2 г/м2/сутки) 1-14дни. } \\
\text { Интервал } 1 \text { неделя. }\end{array}$ \\
\hline 3 & CAF & $\begin{array}{l}\text { Циклофосфамид } \\
\text { Доксорубицин } \\
\text { Фторурацил }\end{array}$ & $\begin{array}{l}100 \text { мг/м2 внутрь или в/м с } 1 \text {-го по 14-й день, } \\
30 \text { мг/м2 в/в в 1-й и 8-й день } \\
500 \text { мг/м2 в/в в } 1 \text {-й и 8-й день. } \\
\text { Повторить через } 4 \text { недели. }\end{array}$ \\
\hline 4 & FAC & $\begin{array}{l}\text { Фторурацил } \\
\text { Доксорубицин } \\
\text { Циклофосфамид }\end{array}$ & $\begin{array}{l}500 \text { мг/м2 в/в в } 1 \text {-й день, } \\
50 \text { мг/м2 в/в в 1-й день, } \\
500 \text { мг/м2 в/в в } 1 \text {-й день. } \\
\text { Повторить через } 3 \text { недели. }\end{array}$ \\
\hline 5 & FEC & $\begin{array}{l}\text { Фторурацил } \\
\text { Эпирубицин } \\
\text { Циклофосфамид }\end{array}$ & $\begin{array}{l}500 \text { мг/м2 в/в в } 1 \text {-й день, } \\
50-100 \text { мг/м2 в/в в 1-й день, } \\
500 \text { мг/м2 в/в в } 1 \text {-й день. } \\
\text { Повторить через } 3 \text { недели. }\end{array}$ \\
\hline 6 & $A C$ & $\begin{array}{l}\text { Доксорубицин } \\
\text { Циклофосфамид }\end{array}$ & $\begin{array}{l}60 \text { мг/м2 в/в } 1 \text {-й день, } \\
600 \text { мг/м2 в/в в 1-й день. } \\
\text { Повторить через } 21 \text { день. }\end{array}$ \\
\hline 7 & DA & $\begin{array}{l}\text { Доксорубицин } \\
\text { Доцетаксел (таксотер) }\end{array}$ & $\begin{array}{l}50 \text { мг/м2 в/в в } 1 \text { й день, } \\
75 \text { мг/м2 инфузия } 1 \text { час в 1-й день. Перерыв } 3 \text { недели }\end{array}$ \\
\hline 8 & PA & $\begin{array}{l}\text { Доксорубицин } \\
\text { Паклитаксел (Таксол) }\end{array}$ & $\begin{array}{l}50 \text { мг/м2 в/в в } 1 \text {-й день, } \\
\text { Затем:175мг/м2 в/в инфузия } 3 \text { ч после премедикации } \\
\text { (не ранее чем через } 4 \text { ч после доксорубицина!). } \\
\text { Перерыв } 3 \text { недели }\end{array}$ \\
\hline
\end{tabular}


Таблица 2. Режимы химиопрепаратов, применённые у 86 пациенток для химиотерапии по поводу рака молочной железы

\begin{tabular}{|c|c|c|c|}
\hline $\begin{array}{l}\text { № } \\
\text { п/ா }\end{array}$ & Схема & Название химиопрепарата & Доза химиопрепарата и режимы \\
\hline 9 & CNF & $\begin{array}{l}\text { Циклофосфамид } \\
\text { Новантрон } \\
\text { Фторурацил }\end{array}$ & $\begin{array}{l}500 \text { мг/м2 в/в в } 1 \text {-й день, } \\
10 \text { мг/м2 в/в в 1-й день, } \\
500 \text { мг/м2 в/в в 1-й день. } \\
\text { Повторение через } 3 \text { недели. }\end{array}$ \\
\hline 10 & NFL & $\begin{array}{l}\text { Новантрон } \\
\text { Лейковорин } \\
\text { Фторурацил }\end{array}$ & $\begin{array}{l}12 \text { мг/м2 в/в в1 -й день, } \\
300 \text { мг суммарно в/в за } 1 \text { час до фторурацила, } \\
350 \text { мг/м2 в/в в 1,2, 3-й день. } \\
\text { Повторение через } 3 \text { недели. }\end{array}$ \\
\hline 11 & DAC & $\begin{array}{l}\text { Доксорубицин } \\
\text { Доцетаксел (Таксотер) } \\
\text { Циклофосфамид }\end{array}$ & $\begin{array}{l}50 \text { мг/м2 в/в в } 1 \text {-й день, } \\
75 \text { мг/м2 инфузия } 1 \text { час в } 1 \text { й день (после премедикации), } \\
500 \text { мг/м2 в/в в 1-й день. } \\
\text { Перерыв на } 3 \text { недели }\end{array}$ \\
\hline 12 & ED & $\begin{array}{l}\text { Эпирубицин (Фарморубицин) } \\
\text { Доцетаксел (Таксотер) }\end{array}$ & $\begin{array}{l}75 \text { мг/м2 в/в в } 1 \text {-й день, } \\
75 \text { мг/м 21-часовая инфузия в1-й день (на фоне } \\
\text { премедикации). } \\
\text { Перерыв } 3 \text { недели. }\end{array}$ \\
\hline 13 & TCis & $\begin{array}{l}\text { Доцетаксел (Таксотер) } \\
\text { Цисплатин }\end{array}$ & $\begin{array}{l}75 \text { мг/м2 в/в инфузия в течение } 1 \text { ч. в 1-й день, } \\
75 \text { мг/м2 в/в в1-й день. } \\
\text { Повторение через } 3 \text { недели. }\end{array}$ \\
\hline 14 & TN & $\begin{array}{l}\text { Доцетаксел (Таксотер) } \\
\text { Винорельбин (Навельбин) }\end{array}$ & $\begin{array}{l}75 \text { мг/м2 1-часовая инфузия (после премедикации)в1-й } \\
\text { день, } \\
20 \text { мг/м2 в/в в1-й и 5-й день. Повторить через } 3 \text { недели. }\end{array}$ \\
\hline 15 & CisT & $\begin{array}{l}\text { Цисплатин } \\
\text { Паклитаксел (Таксол) }\end{array}$ & $\begin{array}{l}60 \text { мг/м2 в/в в } 1 \text {-й день, } \\
90 \text { мг/м2 3-часовая инфузия в 1-й день (на фоне } \\
\text { премедикации). } \\
\text { Повторение курса через } 2 \text { недели, всего 4-6 курсов. }\end{array}$ \\
\hline 16 & TN & $\begin{array}{l}\text { Паклитаксел (Таксол) } \\
\text { Навельбин }\end{array}$ & $\begin{array}{l}\text { 135мг/м2 3-часовая инфузия в 1-й день (на фоне } \\
\text { премедикации). } \\
\text { 20мг/м2 в/в в 1-й и 8-й день.Повторить через } 3 \text { недели. }\end{array}$ \\
\hline 17 & NCis & $\begin{array}{l}\text { Винорельбин (Навельбин) } \\
\text { Цисплатин }\end{array}$ & $\begin{array}{l}\text { 20мг/м2 в/в в1-й и 15-й день } \\
80 \text { мг/м2 в/в в } 1 \text {-й день. } \\
\text { Повторение через } 28 \text { дней. }\end{array}$ \\
\hline 18 & CACis & $\begin{array}{l}\text { Циклофосфамид } \\
\text { Доксорубицин } \\
\text { Цисплатин }\end{array}$ & $\begin{array}{l}400 \text { мг/м2 в/в в } 1 \text {-й день, } \\
40 \text { мг/м2 в/в в } 1 \text {-й день, } \\
40 \text { мг/м2 в/в с1 по3- й день. } \\
\text { Повторить через } 3 \text { недели. }\end{array}$ \\
\hline 19 & MMM & $\begin{array}{l}\text { Митомицин } \\
\text { Митоксантрон (Новантрон) } \\
\text { Метотрексат }\end{array}$ & $\begin{array}{l}8 \text { мг/м2 в/в в } 1 \text {-й день, } \\
8 \text { мг/м2 в/в в 1-й день, } \\
30 \text { мг/м2 в/в в 1-й день. } \\
\text { Повторить через } 5 \text { недель. } \\
\end{array}$ \\
\hline 20 & TCisH & $\begin{array}{l}\text { Доцетаксел (Таксотер) } \\
\text { Цисплатин } \\
\text { Трастузумаб (Герцептин) }\end{array}$ & $\begin{array}{l}70 \text { мг/м2 в/в в 1, 22, 43, 64-й день, } \\
70 \text { мг/м2 в/в в 1, 22, 43, 64-й день, } \\
4 \text { мг/кг в } 1 \text {-й день, далее } 2 \text { мг/кг1 раз в неделю в течение } \\
11 \text { недель. }\end{array}$ \\
\hline 21 & GT & $\begin{array}{l}\text { Гемцитабин (Гемзар) } \\
\text { Паклитаксел (Таксол) }\end{array}$ & $\begin{array}{l}\text { 1000мг/м2 в/в в1-й, 8-й день } \\
\text { 175мг/м2 3-часовая инфузия в 1-й день. } \\
\text { Повторить через } 3 \text { недели. }\end{array}$ \\
\hline 22 & GT & $\begin{array}{l}\text { Гемцитабин (Гемзар) } \\
\text { Доцетаксел (Таксотер) }\end{array}$ & $\begin{array}{l}900 \text { мг/м2 в/в в 1-й,8-й день, } \\
75 \text { мг/м2 в/в в 8-й день. } \\
\text { Повторить через } 3 \text { недели. }\end{array}$ \\
\hline 23 & GA & $\begin{array}{l}\text { Гемцитабин (Гемзар) } \\
\text { Доксорубицин }\end{array}$ & $\begin{array}{l}\text { 1000мг/м2 в/в в 1-й,8-й день } \\
60 \text { мг/м2 в/в в 1-й день. } \\
\text { Повторить через } 3 \text { недели. }\end{array}$ \\
\hline
\end{tabular}


Таблица 3. Чувствительность химиопрепаратов к раку молочной железы у 86 пациенток основной группы

\begin{tabular}{|l|l|l|}
\hline Группа химиопрепаратов & Название химиопрепарата & Чувствительность в процентах \\
\hline антрациклины & $\begin{array}{l}\text { Доксорубицин } \\
\text { (адриамицин) }\end{array}$ & $42 \pm 1,5$ \\
\hline хлорэтиламины & циклофосфамид & $35 \pm 1,7$ \\
\hline антагонисты фолиевой кислоты & метотрексат & $35 \pm 1,5$ \\
\hline антагонисты пиримидина & фторурацил & $35 \pm 1,5$ \\
\hline таксаны & таксол (паклитаксел) & $60 \pm 2,2$ \\
\hline таксаны & таксотер (доцетаксел) & $80 \pm 2,8$ \\
\hline винкаалкалоиды & навельбин (винорельбин) & $50 \pm 1,5$ \\
\hline антагонисты пиримидина & капецитабин (кселода) & $35 \pm 1$ \\
\hline антагонисты пиримидина & гемзар (гемцитабин) & $25 \pm 1$ \\
\hline соединения платины & цисплатин & $60 \pm 2,5$ \\
\hline таргентный препарат & герцептин (трастузумаб) & $70 \pm 2.5$ \\
\hline антрациклины & карминомицин & $40 \pm 1,5$ \\
\hline антрацендионы & митоксантрон & $40 \pm 1,3$ \\
\hline & & Р<0,005 \\
\hline
\end{tabular}

водили до 6 курсов. Применение той или иной схемы зависело от наличия химиопрепаратов, чувствительности химиопрепарата (табл. 3) и переносимости организмом больных. Монохимиотерапия проведена у ограниченного количества больных.

\section{Обсужление}

Cхема CMF применялась обычно у пожилых, соматически отягощённых пациенток. Режим ТС (таксофер + циклофосфан) удобен оказался для пациенток с кардиальной патологией, так как отсутствуют в схеме антрациклины. Хорошие результаты показала схема КСФ (карминомицин + циклофосфан + фторурацил), чем схема AC. При режиме ТАС (доцетаксел + адриабластин + циклофосфамид) установлена проблема миелосупрессий и стоматитов. По этой причине не является приоритетной схема ТАС. При отсутствии чувствительности химиопрепараты менялись на чувствительные для химитерапии рака молочной железы (табл. 3). В связи с тем, что у пациенток (86) основной группы определяли чувствительность химиопрепарата к раку молочной железы, не установлены рецидивы и метастазы в данной группе пациенток. В группе сравнения у 89 пациенток с раком молочной железы установленные рецидивы у 9 пациенток и метастазы у 4, по-видимому, связаны с тем, что были использованы не чувствительные химиопрепараты или появилась резистентность к раку молочной железы у этих пациенток.

\section{Выво $\triangle \mathrm{b}$}

1. Разработан способ определения чувствительности химиопрепарата к раку молочной железы и применён в клинике у 86 пациенток.

2. Новый способ определения чувствительности химиопрепарата к раку молочной железы доступен для республиканских онкологических учреждений, прост и эффективен.

3. Клинические испытания показали, что новый способ определения чувствительности химиопрепарата к раку молочной железы способствует улучшению результатов химиотерапии рака молочной железы.

\section{ЛИТЕРАТУРА}

1. Белохвостова А.С. Химиолучевая терапия в комбинированном лечении местнораспространенного Her-2-позитивного рака молочной железы: автореф. Дис., к.м.н.: 14.01.13 / Белохвостова А.С.— Обнинск. - 2018. - 21 с.

2. Переводчикова Н.И. Руководство по химиотерапии опухолевых заболеваний, 4 изд. - М.: Издательство «Практическая медицина», 2018. - 668 с.

3. Богуш Т.А., Дудко Е.А., Тихомиров М.В. и соавт. Способ иммунофлуоресцентного анализа маркеров множественной лекарственной резистентности в солидных опухолях человека // Патент.— 2017. RU2 413948 C1.

4. Иншаков А.Н. Фармако-динамическое моделирование чувствительности опухолевых клеток хронического лимфолейкоза и множественной миеломы к химиопрепаратам in vitro: автореф. дисс., к.м.н.: 14.01.02 / Иншаков А.Н.— Москва.— 2012.—C. 25. 
5. Клименко В.В. Молекулярные маркеры эффективности предоперационной химиотерапии местно-распространенного рака молочной железы: автореф. дисс..., к.м.н.: 14.01.12 / Клименко Вероника Викторовна.—- ППб.-2015.— 24 с.

6. Кит 0.И., Саманеева Н.Ю., Владимирова Л.Ю. и соавт. Способ оценки чувствительности опухоли к проводимой химиотерапии больных местно-распространенным раком молочной железы // Патент.— 2017. RU2 616532 C1. 7.

7. Dawood S., Broglio K., Valero V. et al. Circulating tumor cells in metastatic breast cancer: from prognostic stratification to modification of the staging system? Cancer. - 2008. - 113(9). - 2422-30.

8. Giraud S., Loum E. Bessette B., Feimeaux V. Tautrette T. Oncogramme, a new promising method for individualized breast tumour response testing for cancer treatment // Anticancer Res. - 2001.—31.— № 1.- P. 139-145.

9. Ly A., Lester S.C., Dillon D. Prognostic factors for patients with breast cancer, traditional and new. Surgical pathology. - 2012. - 5. - 775-785.

10. Рамазанов М.Р., Нестеров М.И., Рамазанова 3.М. Способ определения чувствительности злокачественной опухоли к химиопрепарату // Патент.- 2014. RU2 534410 С2. Опубл. 2014.11.27.

( Рамазанов Муталим Рамазанович ( rm.06-50@уandex.ru ), Абдурахманова Загидат Мутаэлумовна (Abdurakhmava@gmail.com ). Журнал «Современная наука: актуальные проблемы теории и практики»

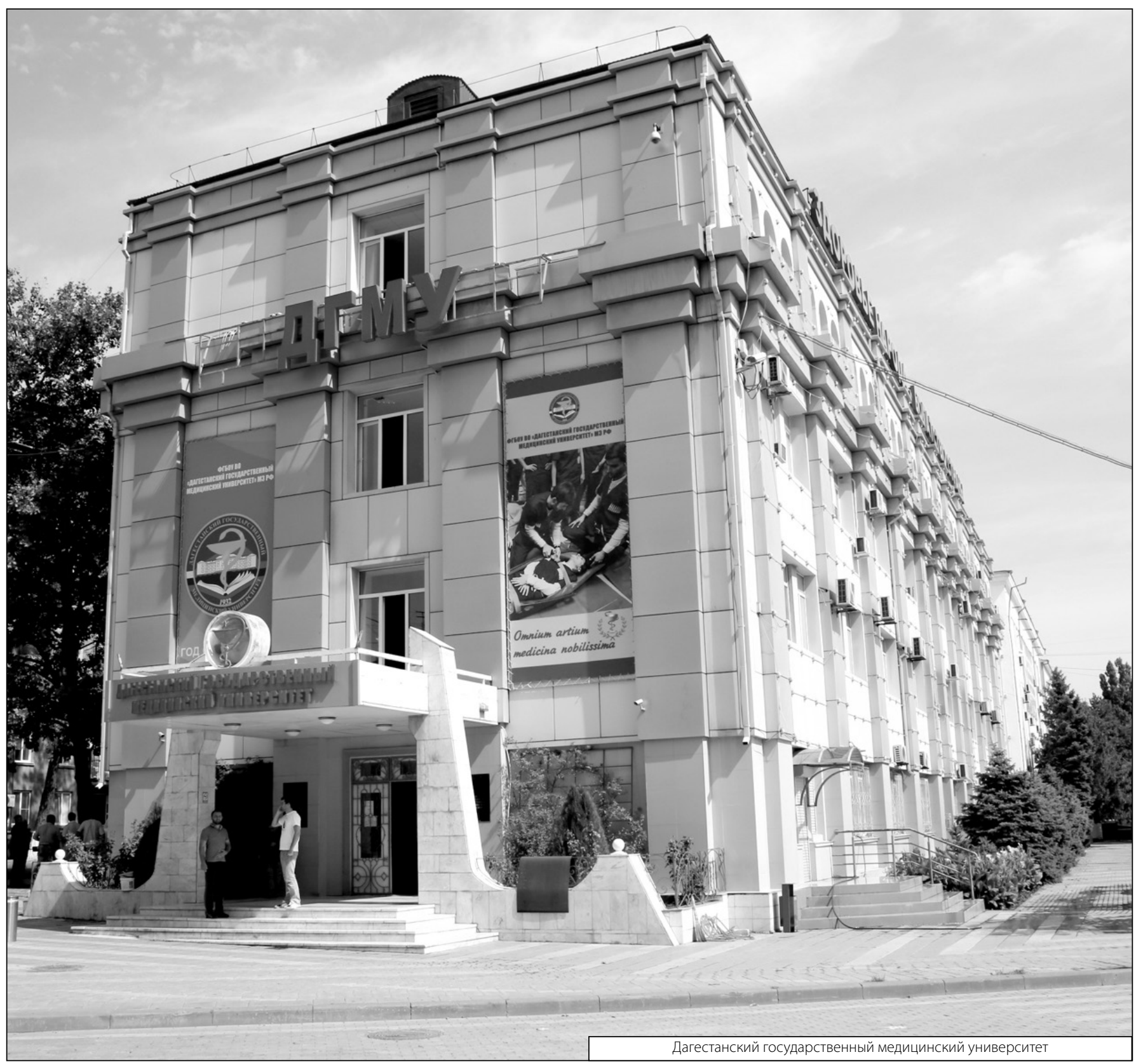

